\title{
Isolation and intracellular localization of insulin-like proteins from leaves of Bauhinia variegata
}

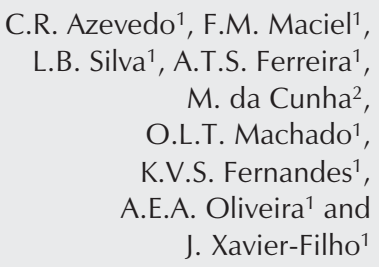

\author{
'Laboratório de Química e Função de Proteínas e Peptídeos, \\ ${ }^{2}$ Laboratório de Biologia Celular e Tecidual, Centro de Biociências e Biotecnologia, \\ Universidade Estadual do Norte Fluminense, Campos dos Goytacazes, RJ, Brasil
}

\author{
Correspondence \\ K.V.S. Fernandes \\ Laboratório de Química e Função \\ de Proteínas e Peptídeos \\ Centro de Biociências e \\ Biotecnologia, UENF \\ Av. Alberto Lamego, 2000 \\ 28013-602 Campos dos Goytacazes, \\ RJ \\ Brasil \\ Fax: +55-22-2726-1520 \\ E-mail: cowpkat@uenf.br \\ Research supported by FAPERJ, \\ CNPq, CAPES, FENORTE, PRONEX, \\ and Universidade Estadual do \\ Norte Fluminense Darcy Ribeiro. \\ Some of the results presented here \\ were taken from the Master's thesis \\ of C.R. Azevedo (see Ref. 22), \\ presented to the Centro de \\ Biociências e Biotecnologia, \\ Universidade Estadual do Norte \\ Fluminense, Campos dos Goytacazes, \\ RJ, Brazil; 2003.
}

\begin{abstract}
Evidence based on immunological cross-reactivity and anti-diabetic properties has suggested the presence of insulin-like peptides in plants. The objective of the present study was to investigate the presence of insulin-like proteins in the leaves of Bauhinia variegata ("pata-de-vaca", "mororó"), a plant widely utilized in popular medicine as an anti-diabetic agent. We show that an insulin-like protein was present in the leaves of this plant. A chloroplast protein with a molecular mass similar to that of bovine insulin was extracted from 2$\mathrm{mm}$ thick 15\% SDS-PAGE gels and fractionated with a $2 \times 24 \mathrm{~cm}$ Sephadex G-50 column. The activity of this insulin-like protein $(0.48$ $\mathrm{mg} / \mathrm{mL}$ ) on serum glucose levels of four-week-old Swiss albino (CF1) diabetic mice was similar to that of commercial swine insulin used as control. Further characterization of this molecule by reverse-phase hydrophobic HPLC chromatographic analysis as well as its antidiabetic activity on alloxan-induced mice showed that it has insulin-like properties. Immunolocalization of the insulin-like protein in the leaves of $B$. variegata was performed by transmission electron microscopy using a polyclonal anti-insulin human antibody. Localization in the leaf blades revealed that the insulin-like protein is present mainly in chloroplasts where it is also found associated with crystals which may be calcium oxalate. The presence of an insulin-like protein in chloroplasts may indicate its involvement in carbohydrate metabolism. This finding has strengthened our previous results and suggests that insulin-signaling pathways have been conserved through evolution.
\end{abstract}

Key words

- Bauhinia variegata

- Plant insulin

- Chloroplast

- Medicinal plant
Received October 10, 2005 Accepted August 25, 2006 ...................

\section{Introduction}

The presence of insulin-like proteins in plants has been investigated since the discovery of insulin in the pancreas of dogs early in the last century (1-3). Collip (2) reported on the hypoglycemic activity of extracts of sev- eral plants when administered to normal rabbits and depancreatized dogs. He named the protein detected in these extracts "glucokinin" instead of insulin because it did not originate from the islets of Langerhans in the pancreas. Best and Scott (3) also reported that insulinlike materials were present in germinating po- 
tatoes and rice. Soon after, Best (4) showed that beetroot extracts have blood sugar-lowering effects as rapid as those of animal insulin in vivo. The first report on the presence of insulin-like antigens in plants was published by Khanna et al. (5) who isolated and patented an active principle called p-insulin from the fruits of Momordica charantia (6). In addition, materials resembling insulin were described in spinach, rye and Lemna gibba, which were recognized by broad spectrum anti-pork and anti-chicken insulin antibodies and had molecular weights, chromatographic properties and biological activities similar to those of vertebrate insulins (7). Insulin-like antigens were also detected in a wide range of green plants, algae, fungi, and a cyanobacterium by an ELISA assay and Western blotting (8). Bioactive and immunoactive insulins were detected in the unicellular eukaryotes Neurospora crassa and Aspergillus fumigatus, which are fungi, in Tetrahymena pyriformis, a ciliated protozoon (9), and in the prokaryote $E s$ cherichia coli (10). Also, Oliveira et al. (11) and Venâncio et al. (12) isolated proteins from the testa of Canavalia ensiformis seeds and from fruits of Vigna unguiculata, respectively, and showed that they have amino acid sequences identical to that of bovine insulin. A hypoglycemic polypeptide was extracted from $M$. charantia seeds. On the basis of sodium dodecyl sulfate-polyacrylamide gel electrophoresis (SDS-PAGE) and its amino acid composition, it was concluded that it was a plant insulin (13).

The objective of the present study was to characterize an insulin-like protein in B. variegata leaves, utilized worldwide for antidiabetic treatments in popular medicine and localize this protein in the tissues of the plant.

\section{Material and Methods}

\section{Plant material}

Leaves of B. variegata L. var. alboflava Dewit (Leguminoseae, Caesalpinioideae) plants, which have white flowers, were collected from specimens growing in private gardens in Campos dos Goytacazes (RJ, Brazil) and identified by João Marcelo A. Braga (Jardim Botânico, Rio de Janeiro, RJ, Brazil). After thoroughly washing, leaf blades were freeze-dried and then reduced to a fine powder for further analysis.

\section{Antibodies}

The antibodies used were a guinea pig polyclonal anti-human insulin antibody acquired from Peninsula Laboratories, Inc. (San Carlos, CA, USA), a peroxidase-conjugated guinea pig polyclonal anti-IgG antibody, and a guinea pig polyclonal anti-IgG antibody conjugated with colloidal gold particles, both from Sigma (St. Louis, MO, USA).

\section{Cytochemical immunolocalization}

Leaves were thoroughly washed, cut into pieces $(0.5 \times 0.5 \mathrm{~cm})$ and fixed in $50 \mathrm{mM}$ sodium cacodylate buffer, $\mathrm{pH} 7.0$, containing $0.1 \%$ glutaraldehyde and $4 \%$ paraformaldehyde for $2 \mathrm{~h}$ at room temperature. Samples were washed three times for $10 \mathrm{~min}$ with the same buffer and dehydrated in 50\% (30 min), 70\% (60 min), and 90\% methanol (60 min). After dehydration the pieces were embedded in LR Gold resin (50, 70, and $100 \%$ resin in methanol) for a total of 6 days. For immunocytochemical localization, sections of approximately $60 \mathrm{~nm}$ were cut from the resin blocks and collected on Formvar films. The sections were treated with $50 \mathrm{mM}$ ammonium chloride for $1 \mathrm{~h}$ and with PBS (10 mM sodium phosphate, $150 \mathrm{mM}$ sodium chloride) containing $1 \%$ bovine serum albu$\min (\mathrm{BSA})$ for $2 \mathrm{~h}$. The sections were then incubated with a guinea pig anti-human insulin antibody (1:200) in the above buffer for $2 \mathrm{~h}$. The sections were then washed six times each for 5 min with PBS plus 1\% BSA as blocking buffer and four times $(5 \mathrm{~min}$ each) with PBS alone. After washing, sec- 
tions were incubated with a guinea pig antiIgG antibody conjugated with colloidal gold $(10 \mathrm{~nm})$ at 1:350 dilution for $2 \mathrm{~h}$ and washed again. The sections were then contrasted with $5 \%$ uranyl acetate followed by $1 \%$ lead citrate for $1 \mathrm{~min}$. The sections were examined and photographed with an Omega 900 Zeiss transmission electron microscope operating at $80 \mathrm{KV}$. Controls were run using only the guinea pig anti-IgG antibody conjugated with colloidal gold.

\section{Crystalline inclusions}

The crystalline inclusions in leaves of $B$. variegata were analyzed by energy-dispersive $\mathrm{X}$-ray microanalysis. After fixation with $2.5 \%$ glutaraldehyde, $4 \%$ paraformaldehyde and $50 \mathrm{mM}$ cacodylate the samples were dehydrated in ethanol and critical point dried in $\mathrm{CO}_{2}$ - covered carbon in a Balzer Apparatus (Santa Ana, CA, USA). Samples were analyzed with a Zeiss DSM 962 scanning electron microscope (Carl Zeiss Inc., Jena, Germany) attached to a Link Oxford system (Oxon, UK) equipped with an X-ray microanalysis system.

\section{Chloroplast purification}

Chloroplasts were isolated by the procedure described by Marcos and Flores (14), with some modifications. Five grams of $B$. variegata leaves was gently homogenized at $4^{\circ} \mathrm{C}$ in a mortar with two volumes (w/v) of a grinding buffer containing $0.35 \mathrm{M}$ sucrose, $3 \mathrm{mM}$ EDTA, $0.1 \%$ (w/v) BSA, $50 \mathrm{mM}$ Tris$\mathrm{HCl}, \mathrm{pH} 7.2$, and $10 \mathrm{mM}$ mercaptoethanol. The homogenate was filtered through four layers of cheesecloth and the filtrate was centrifuged at $250 \mathrm{~g}$ for $10 \mathrm{~min}$ at $4^{\circ} \mathrm{C}$. The supernatant was then centrifuged at $3000 \mathrm{~g}$ for $10 \mathrm{~min}$ at the same temperature. The pellet containing chloroplasts was resuspended in $2 \mathrm{~mL}$ of grinding buffer and the quality of the preparation was analyzed by phase contrast light microscopy.

\section{Extraction of proteins from electrophoresis gels}

Chloroplast proteins were extracted from 2-mm thick 15\% SDS-PAGE gels by the syringe maceration extraction method (15). After electrophoresis (ten gels) the band, with a mass similar to that of bovine insulin, was sliced horizontally into 0.5 -cm sections. The gel slices ( $\sim \mathrm{g}$ of gel material) were placed in a 3-mL syringe and forced through the opening into a second syringe. This procedure was repeated five times. Next, the gel material was collected into a 2-mL Eppendorf tube and $1 \mathrm{~mL}$ of water was added. The mixture was vortexed for $30 \mathrm{~s}$ and left at room temperature for $5 \mathrm{~min}$. The gel material was pelleted by centrifugation at 12,000 $g$ for $1 \mathrm{~min}$ and the supernatant was collected. Ten microliters of the above solution containing the chloroplast insulin-like protein fraction extracted from SDS-PAGE gels was diluted 1:10 in 50\% acetonitrile and used for measuring the absorption spectrum from 220 to $900 \mathrm{~nm}$ in a Specord M500 spectrophotometer.

\section{Partial purification of insulin-like protein}

The supernatant $(400 \mu \mathrm{L})$ containing the chloroplast protein with a molecular mass similar to that of bovine insulin extracted from gels was fractionated with a $2 \times 24 \mathrm{~cm}$ Sephadex G-50 column. The column was previously equilibrated with $0.1 \mathrm{M}$ ammonium bicarbonate, $\mathrm{pH} 7.6$, and eluted at a flow rate of $0.5 \mathrm{~mL} / \mathrm{min}$ with the same buffer. Fractions $(2 \mathrm{~mL})$ were collected and absorbance at 280, 410 and $670 \mathrm{~nm}$ was measured. Fractions were analyzed for the presence of insulin-like antigens by dot blot (data not shown) and quantified by ELISA (see below) using a bovine insulin antibody. Fractions were pooled and further resolved into several components by reverse-phase chromatography through a C2/C18 SC 2.1/ 10 hydrophobic column from Pharmacia 
(Amersham Biosciences of Brazil Ltda., São Paulo, SP, Brazil) in Smart System (Pharmacia LKB Biotechnology, Uppsala, Sweden). The sample ( $25 \mu \mathrm{g}$ protein) was dried in a Speed-Vac rotary evaporator and dissolved in $100 \mu \mathrm{L} 0.1 \%$ TFA. The material was eluted with a $0-80 \%$ acetonitrile gradient from 0 to $45 \mathrm{~min}$ at a flow rate of $100 \mu \mathrm{L} /$ min. Absorbance was recorded at $280 \mathrm{~nm}$ and the fractions were analyzed for the presence of insulin with bovine insulin antibody by a modified ELISA. Bovine and human insulins were subjected to the same procedure as controls.

\section{Insulin-like protein quantification}

A 96-well microplate (Nunc Maxisorb, Copenhagen, Denmark) was coated at $4^{\circ} \mathrm{C}$ overnight with $100 \mu \mathrm{L}$ of serial dilutions of control insulin solution (bovine insulin, 1 $\mu \mathrm{g} / 100 \mu \mathrm{L})$ and partially purified protein solution $(20 \mu \mathrm{g} / \mathrm{well})$ suspended in $100 \mu \mathrm{L}$ $0.05 \mathrm{M}$ carbonate/bicarbonate buffer, $\mathrm{pH}$ 9.6. The solutions were then discarded and the wells were washed for $1 \mathrm{~h}$ with $0.05 \%$ Tween 20 in $0.1 \mathrm{M}$ phosphate, $0.5 \mathrm{M} \mathrm{NaCl}$, pH 7.6 (TPBS). After washing, each well was incubated with $300 \mu \mathrm{L}$ of a blocking solution (1\% gelatine in TPBS) for $1 \mathrm{~h}$ at room temperature. The wells were washed for $1 \mathrm{~h}$ with $0.05 \%$ Tween 20 in PBS. After washing, $50 \mu \mathrm{L}$ of the anti-human insulin antibody solution diluted 1:2000 was added and left to stand for $2 \mathrm{~h}$ at room temperature. After three washes with TPBS (5 min each), plates were incubated with $50 \mu \mathrm{L}$ of a peroxidase-conjugated anti-IgG antibody (1: 2000) in blocking buffer for $2 \mathrm{~h}$ at room temperature. The plates were then washed three times with TPBS as described above. The substrate for peroxidase (10 mg ortho-phenylenediamine in $25 \mathrm{~mL} 26 \mathrm{mM}$ citrate $/ 52 \mathrm{mM}$ phosphate buffer, pH 5.0, with $10 \mu$ L hydrogen peroxide) was then added and the plates were left to stand for $10 \mathrm{~min}$ in the dark at room temperature. Color development was stopped with $50 \mu \mathrm{L} 3 \mathrm{~N} \mathrm{H}_{2} \mathrm{SO}_{4}$ and absorbance was read at $490 \mathrm{~nm}(16)$. The amount of insulin present was determined from standard curves obtained from the bovine insulin response.

\section{Hypoglycemic activity}

Four-week-old Swiss albino (CF1) mice were used to measure the hypoglycemic activity of the protein isolated from SDS-PAGE of leaf extracts. One hundred microliters of a saline $(0.15 \mathrm{M} \mathrm{NaCl})$ solution of alloxan was injected subcutaneously in mice $(15 \mathrm{mg} / 100$ $\mathrm{g}$ body weight) in order to promote diabetes. Five days after the alloxan inoculation, high glucose levels in the blood of the animals were verified by the orthotoluidine method (17). Five groups of mice of 5 animals each were used in the experiment. After feeding, swine insulin (Sigma; $1 \mathrm{IU} / \mathrm{mL}$, which is equal to $0.48 \mathrm{mg} / \mathrm{mL})$, total leaf extract $(0.48$ $\mathrm{mg} / \mathrm{mL}$ protein) and the protein fraction extracted from the gel $(0.48 \mathrm{mg} / \mathrm{mL}$ protein $)$ were given to three groups of diabetic animals, respectively. All samples were dissolved in $0.15 \mathrm{M} \mathrm{NaCl}$ and $100 \mu \mathrm{L}$ was injected through the caudal vein. Two groups of 5 animals each were used as controls: a group of diabetic mice and a group of normal animals were injected with $100 \mu \mathrm{L} 0.15$ $\mathrm{M} \mathrm{NaCl}$. After $1 \mathrm{~h}$, blood was collected from the ophthalmic venous plexus and the serum collected after centrifugation. Glucose (mg/ $\mathrm{dL}$ ) was measured by the orthotoluidine method (17). The means of the measurements were analyzed statistically by the Student $t$-test for dependent samples, with the level of significance set at $\mathrm{P}<0.05$.

\section{Results}

Microscopic analysis of leaf tissue sections showed that anti-insulin antibodies labeled the chloroplasts of the parenchyma cells (Figure 1, panels A,B,C). We also observed labeled crystals present in the cell 
vacuole (Figure 2, panels A,B). Scanning electron microscopy of these crystals (Figure 2, panel D) and analysis by energydispersive X-ray microanalysis (Figure 3, panels A and B) showed that they consisted mostly of calcium, probably in the form of calcium oxalate (18). Additional experiments were carried out using isolated chloroplasts. Figure 4 shows the electrophoretic profile of proteins from the $B$. variegata leaf extract and the chloroplast fraction. A protein band from the leaf extract with a molecular mass similar to that of bovine insulin was recognized by a human insulin antibody (lane 2') and was accompanied by leaf pigments (lane $3)$. To investigate the nature of the pigment associated with this band, an absorption spectrum of the protein extracted from the gels was run and absorption peaks (data not shown) at 280 (protein), 410 and $670 \mathrm{~nm}$ (characteristic of chlorophyll) were observed. A solution of the insulin-like protein extracted from the gels was filtered through a G-50 Sephadex column (Figure 5, panel A). The eluted fractions $(2 \mathrm{~mL})$ were monitored at 280, 410, and $670 \mathrm{~nm}$ and tested by dot blot analysis (Figure 5, panel B) for the presence of insulin-like molecules. The two fractions

Figure 2. Transmission electron micrographs of Bauhinia variegata leaf blades, showing a crystal (arrows) present in the parenchyma cell. Panel $A$, General aspect of a parenchyma cell (bar $=2.5 \mu \mathrm{m})$; panel $B$, labeled crystal (bar $=0.17 \mu \mathrm{m})$; panel $C$, control crystal (bar $=0.17 \mu \mathrm{m})$; panel $D$, scanning electron microscopy showing the crystal present in $B$. variegata leaf blades (bar $=20 \mu \mathrm{m})$.

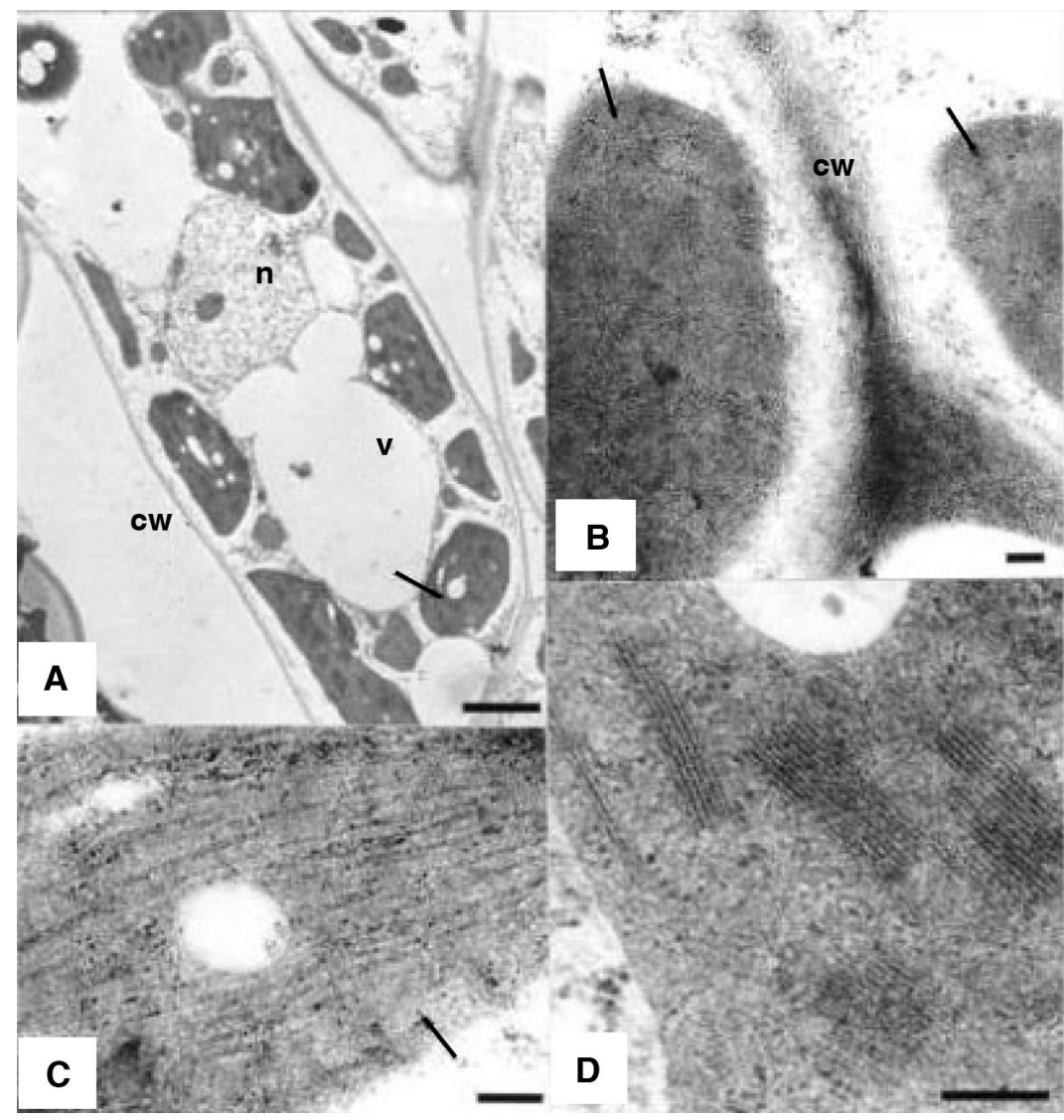

Figure 1. Electron micrographs of Bauhinia variegata leaf blades using transmission electron microscopy. Panel $A$, General aspect of a palisade parenchyma cell (bar $=1.7$ $\mu \mathrm{m})$; panels $B$ and $C$, experimental sections showing immunolabeling in chloroplasts (arrows; bar $=0.15 \mu \mathrm{m}$ ); panel $D$, control chloroplast (bar $=0.15 \mu \mathrm{m}) . \mathrm{n}=$ nucleus; $\mathrm{cw}=$ cell wall; $v=$ vacuole.
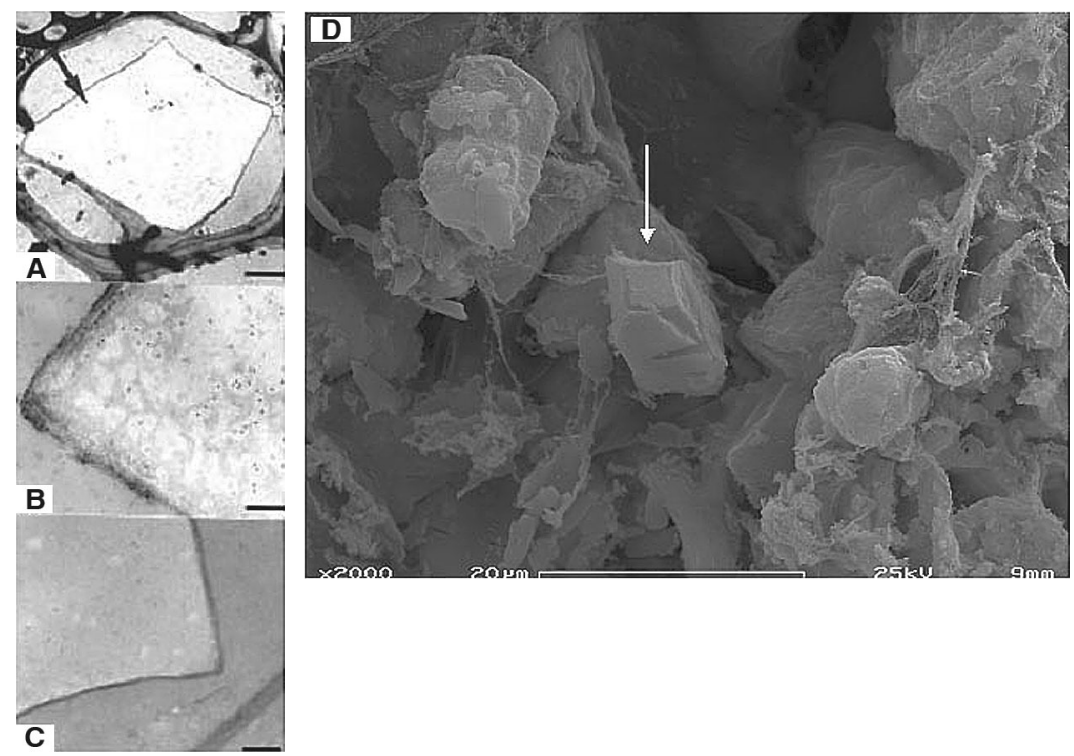
obtained gave positive reactions by ELISA $(\mathrm{G}-1$ fraction $=0.09 \%$ insulin/total protein; $\mathrm{G}-2$ fraction $=0.098 \%$ insulin/total protein) . G-2 fraction (Figure 5), which was free of

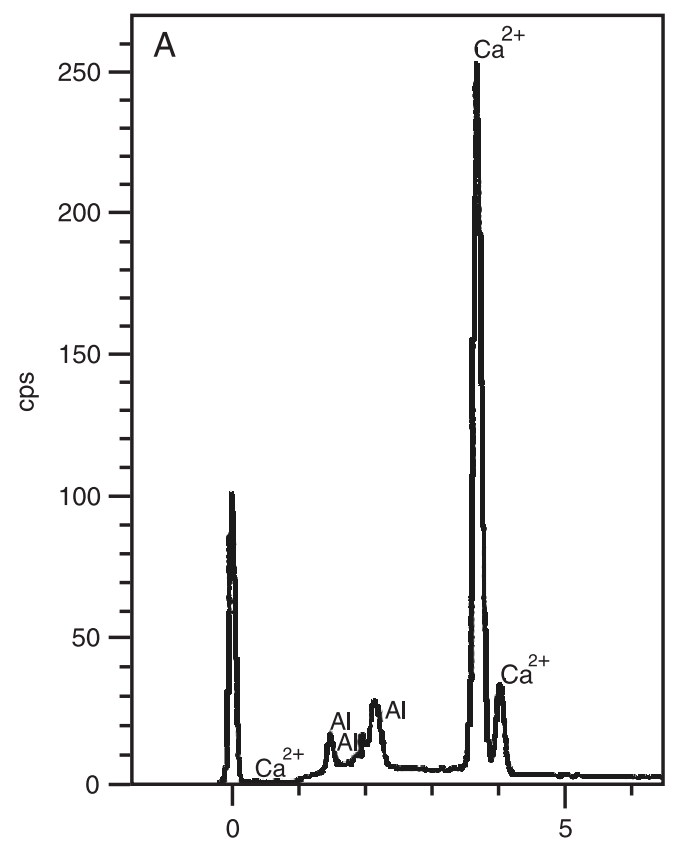

B

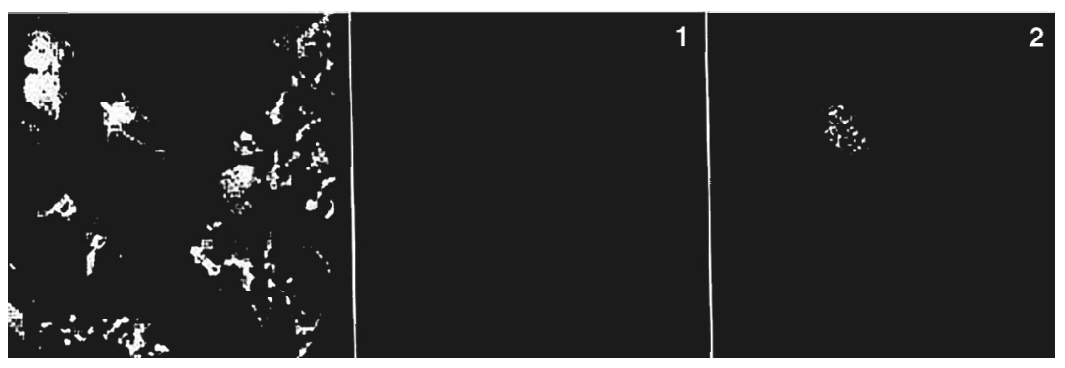

Figure 3. Quantitative analysis of Bauhinia variegata leaf crystals by energy-dispersive Xray microanalysis $(A)$ and visual detection of $\mathrm{Ca}^{2+}$ in leaf crystals $\left.(B) ; 1\right)$ detection of aluminum $(\mathrm{Al})$, and 2$)$ detection of calcium $\left(\mathrm{Ca}^{2+}\right)$.

Figure 4. SDS-PAGE $(A)$ and Western blotting $(B)$ of proteins from Bauhinia variegata leaves. Lanes 1 and 1', 5.7-kDa bovine insulin (arrow) (10 and $30 \mu \mathrm{g}$, respectively); lanes 2 and 2 ', $B$. variegata leaf extract $(30 \mu \mathrm{g})$; lane 3, chloroplast fraction (30 $\mu \mathrm{g})$.

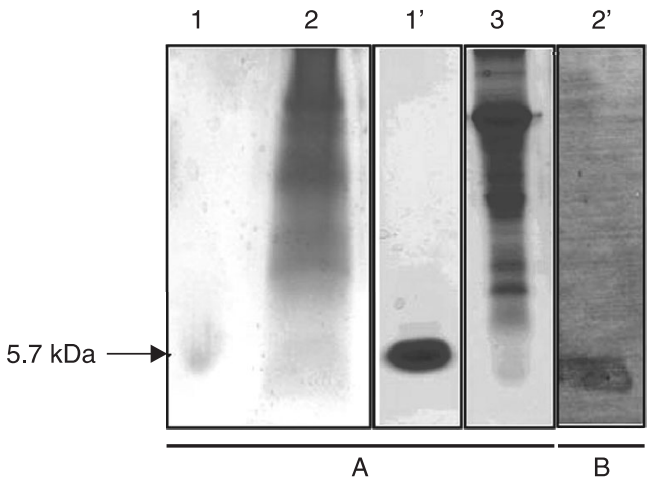

pigments and peroxidase activity, was then submitted to reverse-phase chromatography through a C2-18 column. The eluted fractions were monitored at $280 \mathrm{~nm}$ and tested for insulin by ELISA. A positive reaction by ELISA using both human and bovine antiinsulin antibodies (data not shown) was observed for F7 fraction (Figure 6, panel A), that corresponds to a component of both human and bovine insulin, as seen in Figure 6, panel B.

The effect of the insulin-like protein on serum glucose levels of diabetic mice was determined in experiments in which alloxantreated mice were injected intravenously with the preparation. The leaf extract and the insulin-like protein isolated from leaves of $B$. variegata reduced the glucose levels of the diabetic mice (Figure 7). The hypoglycemic activity of the insulin-like protein isolated from leaves was similar to that of commercial swine insulin used as control.

\section{Discussion}

The leaves of plants of many Bauhinia species (Leguminoseae) are used in antidiabetic treatments by many populations of the world (19). These plants, which are collectively known as cow's foot and "pata-devaca" (in Portuguese) because of the shape of their leaves, are very common in Brazil where investigations have been done in the search for the active principle (19-21). The presence of insulin-like molecules was recently demonstrated in the leaves of $B$. variegata where a protein was found that has a partial amino acid sequence identical to that of bovine insulin. This protein may be responsible for the lowering of blood glucose concentrations when it is injected in diabetic mice (22).

It is known that insulin and insulin-like proteins are present in, and have been isolated from several plants since the discovery of this hormone in the pancreas of dogs at the beginning of the last century $(1,23)$. The 
Figure 5. Chromatographic profile (A) of a Sephadex G-50 molecular exclusion chromatography of proteins extracted from SDS-PAGE gel fractions. Fractions (2 $\mathrm{mL}$ ) were collected and assayed by dot blot (B) with an antibody to human insulin. Absorbance was measured at 280,410 , and $670 \mathrm{~nm}$. In $B$, samples are as follows: 1) $\mathrm{G}-1$ fraction, 2) control for the $\mathrm{G}-1$ fraction, 3) $\mathrm{G}-2$ fraction; 4) control for the G-2 fraction. G-1 fraction = $0.09 \%$ insulin/total protein; $\mathrm{G}-2$ fraction $=0.098 \%$ insulin/total protein

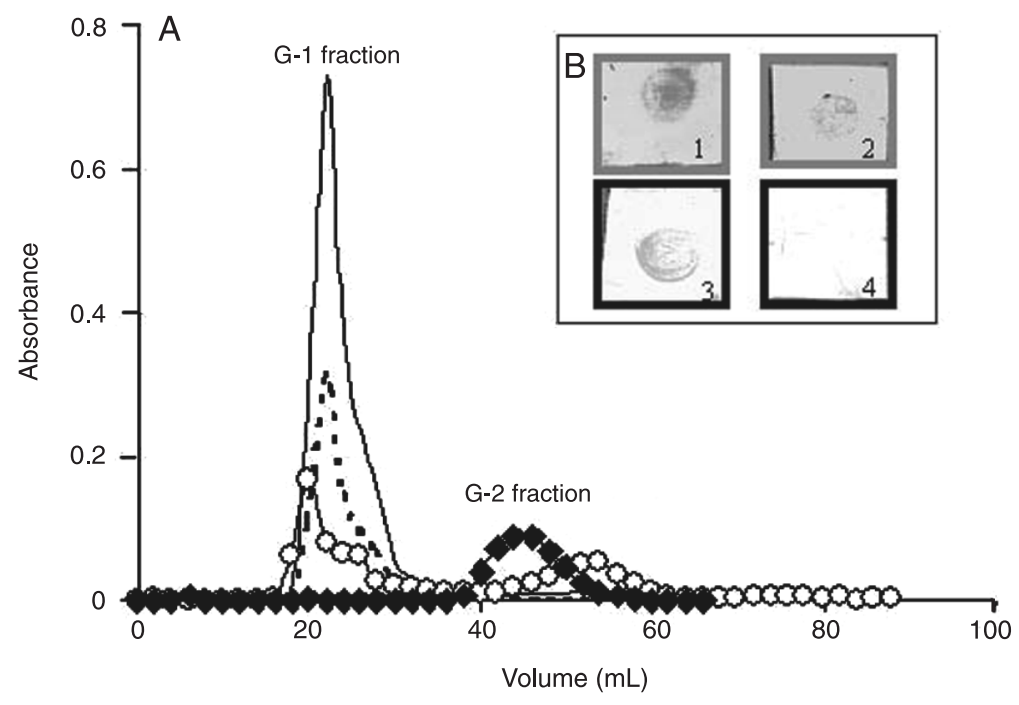

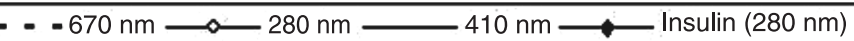
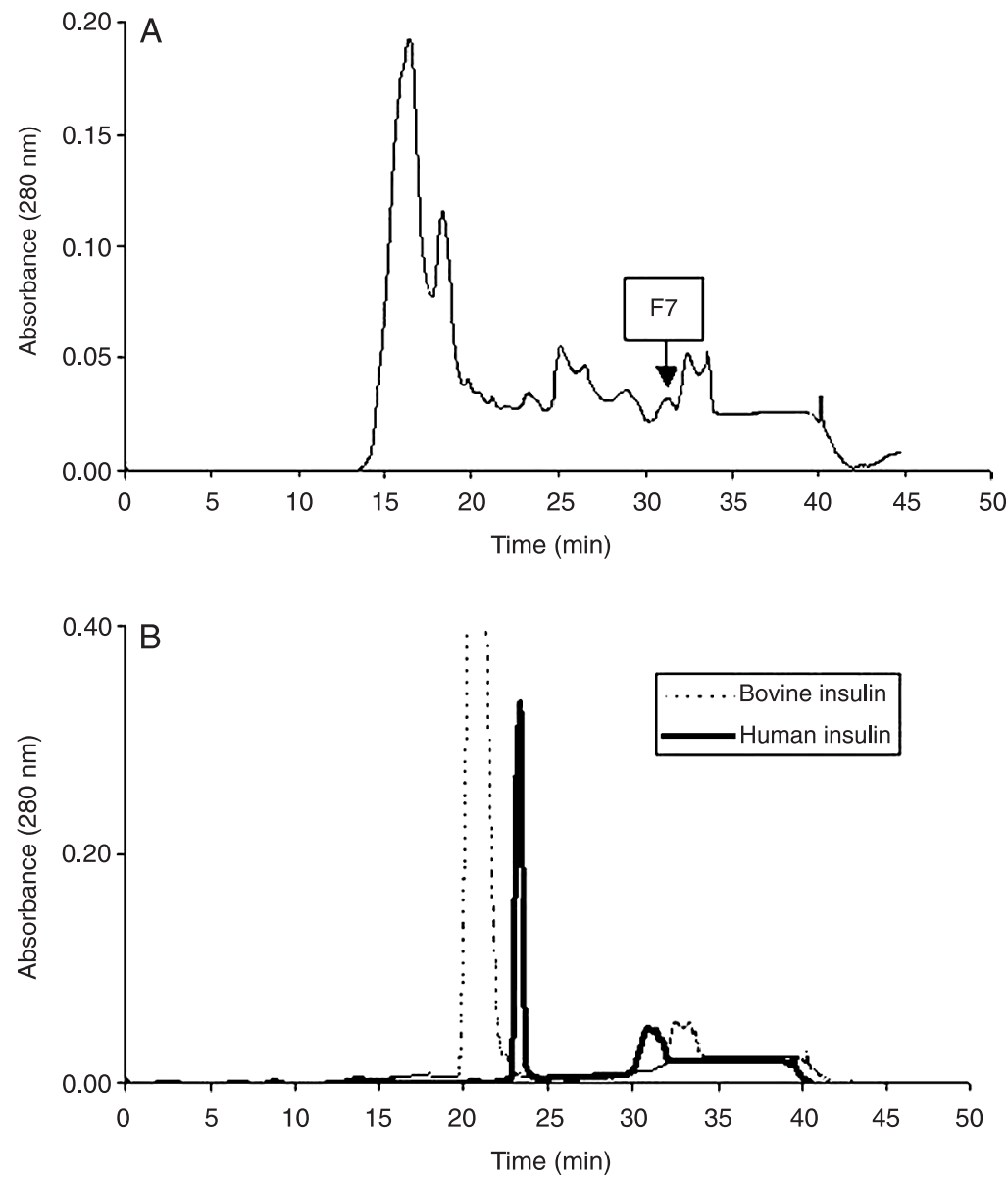

Figure 6. Reverse-phase chromatography (C2-C18) of fraction G-2 from the Sephadex G-50 column (Figure 5). Panel A, Fraction G-2; panel B, bovine and human insulin. Each fraction was assayed by a modified ELISA with human insulin antibody. F7 means the seventh fraction. Absorbance read at $280 \mathrm{~nm}$. 
insulin-like protein from the leaves of $B$. variegata was detected in the chloroplasts by immunocytochemical techniques (Figure 1). Its presence in these organelles was also confirmed by its detection in chloroplasts isolated by centrifugation, gel filtration chromatography and RP-HPLC (Figures 5 and 6). It is interesting to note that in reverse phase chromatography the peak that was positive for insulin by ELISA corresponds to a fraction with a higher hydrophobicity, which is also seen in both human and bovine insulin. These peaks may well correspond to denatured insulin molecules. The immunocytochemical experiments led also to the observation that insulin is associated with calcium-containing crystals in the cell vacuole (Figure 3 ), possibly calcium oxalate crystals (24). This association with crystals containing calcium may protect insulin from proteolysis when the decoctions are ingested, with insulin thus being active on the lowering of blood sugar levels $(21,22,25)$. The effect of the insulin-like protein isolated from B. variegata leaves on glucose levels in the serum of diabetic mice was demonstrated by intravenous injection of the protein fraction extracted from electrophoresis gels. This fraction caused a significant decrease in blood glucose levels in diabetic mice similar to that

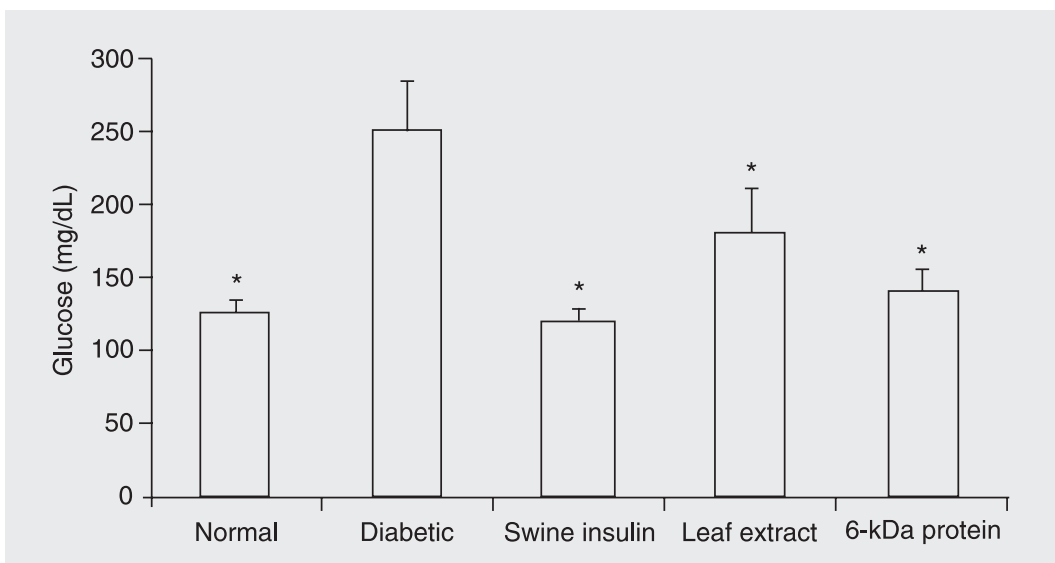

Figure 7. Comparative effects of swine insulin ( $1 \mathrm{IU})$, the extract from the leaves of Bauhinia variegate $(0.48 \mathrm{mg}$ protein $/ \mathrm{mL})$ and the $6-\mathrm{kDa} B$. variegata protein isolated by PAGE $(0.48$ $\mathrm{mg} / \mathrm{mL}$ protein) on the blood glucose levels of alloxan-diabetic mice. ${ }^{*} \mathrm{P}<0.05$ compared to diabetic mice (Student $t$-test). promoted by a preparation of commercial swine insulin. The total leaf extract did not change the glucose levels significantly in diabetic mice (Figure 7), possibly due to a lower insulin concentration.

The first report on the hypoglycemic activity of $B$. forficata in diabetic patients was published by Juliane (20). Recently published study showed that streptozotocin-diabetic rats treated with a decoction of $B$. forficata leaves presented a significant reduction in serum and urinary glucose and urinary urea as compared to streptozotocindiabetic controls (21). Another study, utilizing the oral administration of an n-butanol fraction of B. forficata leaves showed a significant decrease in blood glucose levels in normal and diabetic rats (25).

While it has been previously shown that insulin is present in the testa of $C$. ensiformis (11), in developing fruits of Vigna unguiculata (12) and in M. charantia seeds (13), its functions in plants are not clear at present (23). Nevertheless, its localization in these tissues and the timing of its appearance suggest that insulin in plants has metabolic functions similar to those it exerts on animals, at least in connection with carbohydrate metabolism (23). Several lines of evidence suggest that hexoses (glucose) generated by starch breakdown in the dark in chloroplasts are transported into the cytosol via a glucose translocator $(26,27)$. In view of the results reported here and of others previously published (23), it is tempting to speculate that insulin in chloroplasts may be involved in carbohydrate biosynthesis and transport. Experiments using pedigree strains of maize, additions of insulin and glucokinin (insulinlike antigens isolated from maize) showed accelerated development of young seedlings $(28,29)$ and increased development of chloroplast pigments (29). Exogenous insulin has also been shown to accelerate barley seed development (30), to increase the activity of enzymes (fatty acyl CoA dehydrogenase, citrate synthase, malate dehydrogenase, 
isocitrate lyase, and malate synthase) involved in the conversion of stored fat to carbohydrate in the fat-storing seed species, sunflower (Helianthus annuus), watermelon (Citrullus vulgaris) and cucumber (Cucumis sativus) (31) and to induce ribosomal protein synthesis and seedling development from maize seeds (32). Yet, despite the lack of direct evidence of insulin effects on carbohydrate metabolism in plants, many literature reports suggest the existence of proteins with functions, localization and sequences of the corresponding gene or protein similar to proteins that are members of the insulin pathways characteristic of vertebrates (23). Some of these proteins are insulin receptor (tyrosine kinase) (33), insulin receptor sub- strate proteins 1 and 2 (34), glucose transporter (35), phosphatidylinositol 3-kinase (36), hexokinase (37), MAPK pathway (38), and ribosomal S6 kinase (39). Very few peptides have been recognized as signal molecules functioning in plants (40) but the presence of insulin-like molecules, as described here, suggests that they may participate in plant signaling pathways akin to those in which it is involved in animals. Also, the presence of insulin in plants, besides suggesting that traditional remedies obtained from them and utilized worldwide may have a scientific basis, strongly suggests that the signaling pathways in which this hormone is involved may have been conserved throughout evolution (23).

\section{References}

1. Banting FG, Best CH, Collip JB, Campbell WR, Fletcher AA. Pancreatic extracts in the treatment of diabetes mellitus. Can Med Assoc J 1922; 12: 141-146.

2. Collip JB. Glucokinin: A new hormone present in plant tissue. J Biol 1923; 56: 513-543.

3. Best C, Scott MA. Possible sources of insulin. J Metab Res 1923; 3: 177-179.

4. Best CH. Recent work on insulin. Endocrinology 1924; 1: 617-629.

5. Khanna P, Jain SC, Panagariya A, Dixit VP. Hypoglycemic activity of polypeptide-p from a plant source. J Nat Prod 1981; 44: 648-655.

6. Khanna P, Nag TN, Chandrajaia S, Mohan SV. Process for isolation of insulin from plant source. Patent No. U.S. 3: 945-988; 1976.

7. Collier E, Watkinson A, Cleland CF, Roth J. Partial purification and characterization of an insulin-like material from spinach and Lemna gibba G3. J Biol Chem 1987; 262: 6238-6247.

8. Silva LB, Santos SS, Azevedo CR, Cruz MA, Venancio TM, Cavalcante $\mathrm{CP}$, et al. The leaves of green plants as well as a cyanobacterium, a red alga, and fungi contain insulin-like antigens. Braz $\mathrm{J}$ Med Biol Res 2002; 35: 297-303.

9. Le Roith D, Shiloach J, Roth J, Lesniak MA. Evolutionary origins of vertebrate hormones: substances similar to mammalian insulins are native to unicellular eukaryotes. Proc Natl Acad Sci U S A 1980; 77: 6184-6188.

10. LeRoith D, Shiloach J, Roth J, Lesniak MA. Insulin or a closely related molecule is native to Escherichia coli. J Biol Chem 1981; 256: 6533-6536.

11. Oliveira AEA, Machado OLT, Gomes VM, Xavier-Neto J, Pereira $A C$, Vieira JGH, et al. Jack bean seed coat contains a protein with complete sequence homology to bovine insulin. Protein Pept Lett 1999; 6: 15-21.

12. Venancio TM, Oliveira AE, Silva LB, Machado OL, Fernandes KV, Xavier-Filho J. A protein with amino acid sequence homology to bovine insulin is present in the legume Vigna unguiculata (cowpea). Braz J Med Biol Res 2003; 36: 1167-1173.

13. Sheng $\mathrm{Q}, \mathrm{Yao} \mathrm{H}, \mathrm{Xu} \mathrm{H}$, Ling $\mathrm{X}, \mathrm{He} \mathrm{T}$. Isolation of plant insulin from Momordica charantia seeds by gel filtration and RP-HPLC. Zhong Yao Cai 2004; 27: 414-416.

14. Marcos JF, Flores R. Subcellular location of avocado sunblotch viroid in avocado leaves. Plant Sci 1990; 67: 237-244.

15. Scheer JM, Ryan CA. A method for the quantitative recovery of proteins from polyacrylamide gels. Anal Biochem 2001; 298: 130132.

16. Gebara VC, Petricevich VL, Raw I, da Silva WD. Effect of saponin from Quillaja saponaria (molina) on antibody, tumour necrosis factor and interferon-gamma production. Biotechnol Appl Biochem 1995; 22 (Pt 1): 31-37.

17. Dubowski KM. An o-toluidine method for body-fluid glucose determination. Clin Chem 1962; 8: 215-235.

18. Hill CP, Dauter Z, Dodson EJ, Dodson GG, Dunn MF. X-ray structure of an unusual $\mathrm{Ca}^{2+}$ site and the roles of $\mathrm{Zn}^{2+}$ and $\mathrm{Ca}^{2+}$ in the assembly, stability, and storage of the insulin hexamer. Biochemistry 1991; 30: 917-924.

19. da Silva KL, Cechinel V. Plantas do gênero Bauhinia: composição química e potencial farmacológico. Quim Nova 2002; 25: 449-454.

20. Juliane C. Ação hipoglicemiante da unha-de-vaca. Rev Med Pharm, Chim Phys 1929; 2: 165-169.

21. Pepato MT, Keller EH, Baviera AM, Kettelhut IC, Vendramini RC, Brunetti IL. Anti-diabetic activity of Bauhinia forficata decoction in streptozotocin-diabetic rats. J Ethnopharmacol 2002; 81: 191-197.

22. Azevedo CR. Caracterização parcial de insulina de folhas de Bauhinia variegata. [Master's thesis]. Campos dos Goytacazes: Centro de Biociências e Biotecnologia, Universidade Estadual do Norte Fluminense; 2003.

23. Xavier-Filho J, Oliveira AEA, Silva LB, Azevedo CR, Venâncio TM, 
Machado OLT, et al. Plant insulin or glucokinin: a conflicting issue. Bras J Plant Physiol 2003; 15: 67-78.

24. Franceschi VR, Horner HT. Calcium oxalate crystals in plants. Botanical Rev 1980; 46: 361-427.

25. Silva FR, Szpoganicz B, Pizzolatti MG, Willrich MA, de Sousa E. Acute effect of Bauhinia forficata on serum glucose levels in normal and alloxan-induced diabetic rats. J Ethnopharmacol 2002; 83: 3337.

26. Trethewey RN, Rees T. A mutant of Arabidopsis thaliana lacking the ability to transport glucose across the chloroplast envelope. Biochem J 1994; 301 (Pt 2): 449-454.

27. Buchanan BB, Gruissem W, Jones RL. Biochemistry molecular biology of plants. Rockville: Courier Companies, Inc.; 2000.

28. Ellis MM, Eyster WH. Some effects of insulin and glucokinin on maize seedlings. Science 1923; 58: 541-542.

29. Eyster $\mathrm{WH}$, Ellis M. Growth of maize seedlings as affected by glucokinin and insulin. J Gen Physiol 1924; 6: 653-670.

30. Csaba G, Pál K. Effects of insulin, triiodothyronine, and serotonin on plant seed development. Protoplasma 1982; 110: 20-22.

31. Goodman DB, Davis WL. Insulin accelerates the post germinative development of several fat-storing seeds. Biochem Biophys Res Commun 1993; 190: 440-446.

32. Sanchéz de Jiménez E, Beltrán-Penã E, Ortíz-López A. Insulinstimulated ribosomal protein synthesis in maize embryonic axes during germination. Physiol Plant 1999; 105: 148-154.

33. Carpi A, Di Maira G, Vedovato M, Rossi V, Naccari T, Floriduz M, et al. Comparative proteome bioinformatics: identification of a whole complement of putative protein tyrosine kinases in the model flowering plant Arabidopsis thaliana. Proteomics 2002; 2: 1494-1503.

34. Dietrich RA, Richberg MH, Schmidt R, Dean C, Dangl JL. A novel zinc finger protein is encoded by the Arabidopsis LSD1 gene and functions as a negative regulator of plant cell death. Cell 1997; 88: 685-694.

35. Chiou TJ, Bush DR. Molecular cloning, immunochemical localization to the vacuole, and expression in transgenic yeast and tobacco of a putative sugar transporter from sugar beet. Plant Physiol 1996; 110: $511-520$

36. Hong Z, Verma DP. A phosphatidylinositol 3-kinase is induced during soybean nodule organogenesis and is associated with membrane proliferation. Proc Natl Acad Sci U S A 1994; 91: 9617-9621.

37. Moore B, Zhou L, Rolland F, Hall Q, Cheng WH, Liu YX, et al. Role of the Arabidopsis glucose sensor HXK1 in nutrient, light, and hormonal signaling. Science 2003; 300: 332-336.

38. Agrawal GK, Iwahashi H, Rakwal R. Rice MAPKs. Biochem Biophys Res Commun 2003; 302: 171-180.

39. Garcia Flores C, Aguilar R, Reyes de la Cruz H, Albores M, Sanchez de Jimenez E. A maize insulin-like growth factor signals to a transduction pathway that regulates protein synthesis in maize. Biochem J 2001; 358: 95-100.

40. Ryan CA, Pearce G, Scheer J, Moura DS. Polypeptide hormones. Plant Cell 2002; 14 (Suppl): S251-S264. 